\title{
Choroby mitochondrialne, postęp w badaniu i leczeniu
}

\section{Katarzyna Tońska ${ }^{1}$}

\section{Joanna Rusecka ${ }^{1}$}

\section{Ewa Bartnik ${ }^{1,2, 凶}$}

${ }^{1}$ InstytutGenetykiiBiotechnologii, WydziałBiologii Uniwersytetu Warszawskiego, Warszawa ${ }^{2}$ Instytut Biochemii i Biofizyki PAN, Warszawa

$\triangle$ Instytut Genetyki i Biotechnologii, Wydział Biologii Uniwersytetu Warszawskiego, ul. Pawińskiego 5a, 02-106 Warszawa lub Instytut Biochemii i Biofizyki PAN, ul. Pawińskiego 5a, 02-106 Warszawa; e-mail: ebartnik@igib. uw.edu.pl

Artykuł otrzymano 4 czerwca 2018 r. Artykuł zaakceptowano 10 listopada 2018 r.

Słowa kluczowe: mitochondrialny DNA, choroby mitochondrialne

Wykaz skrótów: LHON (ang. Leber hereditary optic neuropathy) - dziedziczne neuropatia wzrokowa Lebera; MELAS (ang. myopathy, encephalopathy, lactic acidosis, stroke-like episodes) - zespół MELAS, miopatia encefalopatia, kwasica mleczanowa, napady udaropodobne; mtDNA - mitochondrialny DNA; NGS (ang. next generation sequencing) - sekwencjonowanie następnej generacji; WES (ang. whole exome sequencing) - sekwencjonowanie całych eksomów

Podziękowania: Badania prowadzone w niniejszej pracy są finansowane ze środków na naukę przyznanych przez Narodowe Centrum Nauki na realizację w latach 2014-2018 projektów 2014/15/B/NZ2/02272 oraz 2014/15/B/ NZ5/00434.

\section{STRESZCZENIE}

Choroby mitochondrialne wynikają z nieprawidłowej funkcji mitochondrialnego systemu fosforylacji oksydacyjnej: łańcucha oddechowego i syntazy ATP, produkującego energię komórkową $w$ formie ATP. Jest to zróżnicowana grupa chorób dziedzicznych o szerokim spektrum objawów klinicznych mogących pojawić się w każdym wieku. Mogą one być wynikiem mutacji zarówno w mitochondrialnym DNA, jak i DNA jądrowym. Duża zmienność fenotypu pacjentów utrudnia ich diagnozowanie. Ostatnie osiągnięcia w dziedzinie diagnostyki i badań genetycznych oraz nowe metody reprodukcyjne są ogromną szansą na poprawę diagnostyki, leczenia i ograniczenie chorób mitochondrialnych. W tej pracy przedstawiono nowe zagadnienia pozwalające lepiej zrozumieć etiologię tych chorób oraz postęp $w$ ich diagnozowaniu.

\section{WPROWADZENIE}

Choroby mitochondrialne wynikają z nieprawidłowego funkcjonowania systemu fosforylacji oksydacyjnej (OXPHOS, ang. Oxidative Phosphorylation System) produkującego ATP. OXPHOS tworzą cztery kompleksy łańcucha oddechowego i syntaza ATP. Mitochondrialny DNA (mtDNA) koduje 13 z 83 białek będących podjednostkami kompleksów enzymatycznych łańcucha oddechowego oraz syntazy ATP (MT-ATP6, MT-ATP8, MT-CO1, MT-CO2, MT-CO3, MT-CYB, MT-ND1, MT-ND2, MT-ND3, MT-ND4, MT-ND4L, MT-ND5, MT-ND6) [1]. Pozostałe białka, niezbędne do prawidłowego funkcjonowania mitochondriów, $\mathrm{w}$ tym pozostałe podjednostki łańcucha oddechowego, kodowane są przez genom jądrowy [1,2].

Szacuje się, że do prawidłowego funkcjonowania mitochondriów potrzebne są produkty ponad 1500 genów jądrowych. Kodowane przez nie białka to nie tylko podjednostki kompleksów systemu fosforylacji oksydacyjnej czy enzymy licznych mitochondrialnych szlaków biochemicznych. To także białka będące składnikami maszynerii odpowiedzialnej za replikację i naprawę mtDNA, a co za tym idzie regulowanie liczby kopii cząsteczek mitochondrialnego DNA w komórkach oraz podziały i fuzje mitochondriów [3-5]. Ponadto białka te przeprowadzają procesy takie jak: transkrypcja genomu mitochondrialnego, translacja mitochondrialna, składanie mitochondrialnych kompleksów białkowych i wiele innych. Mutacja każdego z tych genów może być przyczyną choroby. Zbiorem wszystkich znanych genów, które mogą mieć znaczenie $w$ chorobach mitochondrialnych jest Human MitoCarta2.0 [6]. Opisanych jest tam 1158 genów mitochondrialnych ludzkich i mysich, których produkty, na podstawie badań proteomicznych, analiz mikroskopowych i bioinformatycznych, ze znacznym prawdopodobieństwem lokalizują się w mitochondriach. W grudniu 2016 r. było wiadomo, że w 281 genach znane są patogenne mutacje powodujące choroby u ludzi [7].

Choroby mitochondrialne spowodowane mutacjami $\mathrm{w}$ mitochondrialnym DNA dziedziczone są w linii matczynej, a więc kobieta przekazuje wadliwy mtDNA potomstwu. Przykładem mogą być mutacje punktowe mtDNA: m.11778G>A, m.14484T>C, czy m.3460G>A, które powodują dziedziczną neuropatię wzrokową Lebera (LHON, ang. Leber's hereditary optic neuropathy). Natomiast choroby spowodowane przez mutacje $\mathrm{w}$ genach jądrowych dziedziczone są w sposób mendlowski, i tak w sposób autosomalny dominujący dziedziczone są m.in. mutacje genu SLC25A4 (ANT1), a w sposób autosomalny recesywny mutacje genu POLG [8-10].

W przypadku patogennych wariantów mitochondrialnego DNA częstym zjawiskiem jest heteroplazmia, czyli obecność więcej niż jednego rodzaju mitochondrialnego DNA. W takim przypadku w komórce występuje równocześnie DNA o prawidłowej sekwencji oraz DNA z mutacją. Na ogół udział cząsteczek z mutacją mitochondrialnego DNA musi wynosić ponad $60-80 \%$ by wystąpiły objawy choroby. Znane są jednak nieliczne wyjątki. Na przykład jedna z mutacji w genie kodującym 
tRNA dla reszty tryptofanu wykazuje efekt fenotypowy, nawet gdy jest obecna w mniej niż 25\% cząsteczek mtDNA [11].

Mimo, że warianty patogenne będące przyczyną choroby mitochondrialnej obecne są od urodzenia, jej objawy mogą pojawić się w dowolnym wieku. Oprócz mięśni i układu nerwowego, wykazujących największe zapotrzebowanie na energię, choroba może obejmować właściwie wszystkie narządy. Wiadomo obecnie, że zaburzenia w funkcjonowaniu przewodu pokarmowego, nerek, wątroby, męska bezpłodność czy przedwczesne ustanie funkcjonowania jajników mogą być również skutkiem zaburzenia funkcji OXPHOS [12]. Przyjmuje się, że większość chorób dających objawy w młodym wieku jest wynikiem mutacji w genach jądrowych, natomiast jeżeli objawy pojawiają się u dorosłych, to w $80 \%$ powodowane są przez mutacje mitochondrialne [13].

Dane statystyczne wskazują, że częstość występowania chorób mitochondrialnych wynosi 10:100 000 i może różnić się pomiędzy populacjami oraz grupami wiekowymi pacjentów [13-14]. W ciągu ostatnich kilku lat ukazało się wiele prac przeglądowych dotyczących chorób mitochondrialnych [1-2,12,14-18]. W tym numerze Postępów Biochemii jest zamieszczona obszerna praca dotycząca grupy chorób mitochondrialnych związanych $\mathrm{z}$ mutacjami $\mathrm{w}$ genach kodujących podjednostki mitochondrialnej syntazy ATP [16]. Tutaj przedstawiamy postęp w zrozumieniu i leczeniu chorób mitochondrialnych, który nastąpił w ostatnich latach.

\section{NOWE TRENDY W DIAGNOSTYCE CHORÓB MITOCHONDRIALNYCH}

W ostatnich latach znacząco zmieniły się możliwości diagnostyczne chorób mitochondrialnych. Najważniejszym osiągnięciem jest stosowanie wysokoprzepustowych technik sekwencjonowania następnej generacji (NGS, ang. next generation sequencing), zarówno sekwencjonowania panelowego, jak i eksomowego (WES, ang. whole exome sequencing). Ze względu na rosnącą liczbę wykrywanych mutacji odpowiedzialnych za choroby mitochondrialne i malejący koszt użycia tych technik zaczynają one być powszechne i dają dobre wyniki diagnostyczne, ze skutecznością sięgającą nawet $60 \%$ w przypadku bardzo skrupulatnie dobranych i scharakteryzowanych klinicznie grup pacjentów [12]. Duże znaczenie mają też coraz bardziej rozbudowane bazy danych pacjentów (np. Mitochondrial Disease Sequence Data Resource, MSeqDR) umożliwiające porównanie mutacji i objawów klinicznych, co usprawnia badania i postawienie diagnozy [19].

\section{PODŁOŻE SPECYFICZNOŚCI TKANKOWEJ}

Intrygującym i nie w pełni poznanym zagadnieniem jest tkankowa specyficzność objawów choroby. Dotyczy ona nie tylko chorób powodowanych przez mutacje mitochondrialnego DNA, ale także tych, które są efektem mutacji w genomie jądrowym. Dla chorób powodowanych przez mutacje w mtDNA zjawisko to dobrze tłumaczy przekroczenie progu procentowej zawartości zmutowanego DNA w danej tkance (heteroplazmia). W przypadku chorób powodowanych przez mutacje w jądrowym DNA dość ogólnym wyjaśnieniem mogą być dramatyczne różnice pomiędzy pulami nukleotydów w różnych tkankach. W tkankach niedzielących się poziom trifosforanów nukleotydów jest 1000 razy niższy niż w komórkach, które się dzielą. Zatem nieprawidłowa replikacja mitochondrialnego DNA powodowana przez mutację któregoś z genów kodującego białko wchodzące w skład aparatu replikacyjnego, w największym stopniu będzie zaburzać fizjologię tkanek niedzielących się [12]. Innym, dobrym wyjaśnieniem specyficzności tkankowej są znaczne różnice pomiędzy proteomami mitochondrialnymi różnych narządów i tkanek. Zaobserwowano, że w przypadku myszy [20] mniej więcej połowa białek mitochondrialnych obecna jest we wszystkich badanych narządach, podczas gdy druga połowa wykazuje specyficzność narządową. W przypadku człowieka można się spodziewać podobnego zjawiska. Co więcej, funkcjonowanie mitochondriów w danej tkance może też zmieniać się z wiekiem. Na przykład prawidłowa translacja białek kodowanych $\mathrm{w}$ mitochondrialnym DNA wydaje się szczególnie istotna dla prawidłowego rozwoju i funkcjonowania serca. Jej defekty, w szczególności mutacje jądrowych genów kodujących mitochondrialne aminoacylo syntetazy tRNA oraz mitochondrialnych genów kodujących tRNA, zwykle prowadzą do ciężkiej kardiomiopatii i śmierci we wczesnym dzieciństwie. W przypadku nielicznych dzieci przeżywających ten okres następuje stabilizacja pracy serca do około 6 roku życia, ale w późniejszym wieku pojawiają się zaburzenia funkcjonowania mózgu [12].

\section{TŁO GENETYCZNE I WSPÓŁDZIAŁANIE KILKU WARIANTÓW GENETYCZNYCH}

Kolejnym czynnikiem wpływającym na przebieg choroby jest tło genetyczne. Jego wpływ został udowodniony już wiele lat temu dla dziedzicznej neuropatii wzrokowej Lebera [21]. W przypadku dwóch powodujących ją mutacji (m.11778G>A i m.14484T>C) stwierdzono, że występują one częściej na tle mitochondrialnej haplogrupy J. Jednocześnie wykazano, że ryzyko zachorowania jest wyższe, jeśli mutacja ta występuje na tle tej haplogrupy. Haplogrupy sa to zestawy polimorfizmów o wspólnym pochodzeniu ewolucyjnym, a haplogrupa J jest stosunkowo częstą (około 10\%, choć są znaczące różnice pomiędzy populacjami) haplogrupą europejską. W przypadku mutacji m.11778G>A zwiększone ryzyko utraty wzroku związane jest z podhaplogrupą J1, a w przypadku $\mathrm{m} .14484 \mathrm{~T}>\mathrm{C}$ z J2 [22]. Do niedawna podobnego związku nie udało się zaobserwować w przypadku innych chorób mitochondrialnych. Analiza ponad 30 tysięcy sekwencji mtDNA zdeponowanych w GenBanku wykazała, że jest to zjawisko powszechniejsze, choć w przypadku żadnej z badanych mutacji, nie tak silne, jak dla m.11778G >A i m.14484T>C [23]. Przy okazji tak szeroko zakrojonych badań stwierdzono także, że niektóre warianty patogenne pojawiały się wielokrotnie w toku ewolucji, ale zwykle w kontekście konkretnej haplogrupy. Oznacza to, że haplogrupa mitochondrialna ma wpływ na częstość zachodzenia i utrwalania się przynajmniej niektórych mutacji mitochondrialnych. Mechanizm tego zjawiska jest w tej chwili nieznany [23].

Innym nowym odkryciem jest, że warianty mtDNA, które samodzielnie nie są chorobotwórcze, występując wspólnie $\mathrm{w}$ jednym genomie mitochondrialnym mogą powodować LHON [24]. To, że pierwszy taki przypadek stwierdzono akurat dla LHON możne wyjaśniać fakt, że mutacje prowadzące do tej choroby są zwykle homoplazmatyczne (praktycznie 
wszystkie cząsteczki mtDNA zawierają mutację). Ułatwia to znacznie analizę, bo unika się dodatkowego czynnika, jakim jest wpływ heteroplazmii, często na zróżnicowanym poziomie. Powszechne sekwencjonowanie całego genomu mitochondrialnego $\mathrm{w}$ celach diagnostycznych $\mathrm{z}$ pewnością ujawni więcej takich przypadków, nie tylko dla LHON.

\section{LECZENIE CHORÓB MITOCHONDRIALNYCH W PRAKTYCE}

W przypadku chorób mitochondrialnych nie ma dobrego leczenia. Zazwyczaj stosuje się działania mające na celu spowolnienie postępu choroby, złagodzenie objawów oraz poprawę komfortu życia pacjentów. W tym celu podaje się pacjentom koktajle witaminowe, prowadzi fizjoterapię oraz stosuje leczenie objawowe na przykład przeciwpadaczkowe. Dla LHON wykazano pozytywne efekty pochodnej koenzymu Q10 - idebenonu i jest on od niedawna lekiem zarejestrowanym w Unii Europejskiej. Trwają także próby kliniczne terapii genowej w przypadku tej choroby [25]. Podawany pacjentom konstrukt zawiera ramkę odczytu genu MT-ND4 poprzedzoną sekwencją kodującą sekwencję aminokwasową kierującą do mitochondrium. Wydaje się, że w zasięgu ręki jest leczenie, przynajmniej niektórych chorób związanych z zaburzeniem puli nukleotydów dostępnej dla mitochondriów. Niedobór któregoś deoksynukleotydu w mitochondriach prowadzi do zaburzenia replikacji mtDNA, a w konsekwencji znacznego spadku liczby kopii i rozwoju zwykle ciężkiej miopatii lub encefalomiopatii. Przykładem takiej choroby jest miopatia powodowana przez mutacje genu TK2 kodującego kinazę tymidynową. W jej przypadku dobre efekty przynosi suplementacja nukleozydami.

W toku jest wiele innych prób klinicznych. Wyspecjalizowane Mitochondrial Disease News (http:/ / mitochondrialdiseasenews.com) co tydzień donosi o nowych próbach, na ogół I fazy. W drugiej fazie badań klinicznych (zakończona faza IIA) jest drobnocząsteczkowy związek KH176 będący modyfikacją troloksu, który jest rozpuszczalną w wodzie pochodną witaminy E. Badanie to dobrze pokazuje trudności w opracowywaniu terapii w przypadku tak złożonych chorób. Do badania zakwalifikowano 18 pacjentów z jedną z najczęstszych mutacji mtDNA m.3243A>G. Mutacja ta może powodować zarówno ciężką postać zespołu MELAS (ang. myopathy, encephalopathy, lactic acidosis, stroke-like episodes; miopatia, encefalopatia, kwasica mleczanowa, napady udaropodobne), jak i miopatię mitochondrialną, czy cukrzycę z głuchotą. Z badań na modelach zwierzęcych wiadomo, że KH176 stabilizuje chód. W badaniu klinicznym trudno było zaobserwować statystycznie istotną różnicę, gdyż 16 z 18 pacjentów nie zgłaszało problemów z niestabilnością chodu. Nie było ani jednego objawu, który byłby obecny u wszystkich chorych zakwalifikowanych do badania. Głównym wnioskiem z badania jest jednak to, że KH176 jest lekiem bezpiecznym [26].

W niektórych przypadkach do prób klinicznych nie dochodzi ze względu na zbyt małą liczbę pacjentów. Tutaj dobrym przykładem znowu są zaburzenia puli nukleotydów. Znanych jest niewiele ponad 100 pacjentów z mutacjami genu TK2 i wprawdzie pojedynczy są leczeni nukleozydami, dotychczas nie były prowadzone żadne próby kliniczne. Opisano zaledwie 15 pacjentów chorych na encefalomiopa- tię powodowaną mutacjami genu $R R M 2 B$ (koduje podjednostkę reduktazy rybonukleotydowej). Mimo, że terapia nukleozydami mogłaby być skuteczna także w ich przypad$\mathrm{ku}$, z powodu braku wcześniejszych badań na zwierzętach i właśnie ekstremalnie małej grupy, pacjentom z mutacjami $R R M 2 B$ nukleozydów się nie podaje (sprawa leczenia Charliego Garda z 2017 roku).

Nadzieją dla pacjentów z mutacjami mitochondrialnego DNA jest przeniesienie przedjądrzy, albo wrzeciona kariokinetycznego do, odpowiednio, zygoty pozbawionej przedjądrzy lub oocytu pozbawionego wrzeciona kariokinetycznego pochodzących od zdrowej dawczyni. Całą procedure przeprowadza się pozaustrojowo. W pierwszym przypadku już po zapłodnieniu, w drugim zapłodnienie następuje po transferze wrzeciona. Umożliwia to nieprzekazywanie dziecku przez kobietę mitochondrialnego DNA z patogennym wariantem, gdyż cytoplazma a wraz z nią mitochondria i mitochondrialny DNA pochodzą od dawczyni. Temat prowokuje liczne dyskusje, choć na świecie w wyniku zastosowania tej metody (mimo braku stosownych zezwoleń) urodziło się już jedno dziecko [27]. Procedura ta zwana mitochondrial replacement jest dozwolona w Wielkiej Brytanii po uzyskaniu pozwolenia Human Embryology and Fertilization Authority [28]. W lutym 2018 roku Human Embryology and Fertilization Authority wydało zgodę na zastosowanie tej procedury $\mathrm{u}$ dwóch kobiet.

\section{PODSUMOWANIE}

Choroby mitochondrialne są złożoną i heterogenną grupą chorób genetycznych. Do tej pory sądzono, że objawy choroby dotykają zazwyczaj tkanek o największym zapotrzebowaniu energetycznym (tkanka nerwowa i mięśniowa), jednak ostatnie badania pokazują, że spektrum objawów jest naprawdę szerokie. Aktualnie prowadzonych jest kilka badań klinicznych, jednak ze względu na duże zróżnicowanie grup pacjentów oraz wysokie koszty prowadzenia badań, skuteczne terapie są w zasadzie niedostępne.

Szansą na ograniczenie ryzyka wystąpienia choroby mitochondrialnej wynikającej z mutacji mtDNA jest procedura mitochondrial replacement. Najbliższe lata pokażą, w jakim stopniu jest ona skuteczna.

Niezaprzeczalnie największym osiągnięciem ostatnich lat jest postęp $\mathrm{w}$ diagnostyce chorób mitochondrialnych wynikający z zastosowania WES oraz paneli genetycznych. Otrzymywane wyniki nie tylko umożliwiają postawienie szybkiej diagnozy. Poszerzają one wiedzę na temat etiologii chorób mitochondrialnych, a w przyszłości pozwolą na zastosowanie celowanych terapii przeznaczonych dla pacjentów z wybranymi i dobrze scharakteryzowanymi defektami genetycznymi.

\section{PIŚMIENNICTWO}

1. Bartnik E, Tońska K (2017) Choroby mitochondrialne. W: Jerzy Bal (red) Genetyka medyczna i molekularna. PWN Warszawa, str. 325-337

2. Piotrowska A, Jankauskaite E, Bartnik E (2016) Choroby mitochondrialne. Postępy Biochem 62: 111-115

3. Tyynismaa H, Peltola K, Wanrooij S, Lappalainen I (2005) Mutant mitochondrial helicase Twinkle causes multiple mtDNA deletions 
and a late-onset mitochondrial disease in mice. Proc Natl Acad Sci USA 102: 17687-17692

4. DeBalsi K, Hoff K, Copeland W (2016) Role of the mitochondrial DNA replication machinery in mitochondrial DNA mutagenesis, aging and age-related diseases. Ageing Res Rev 33: 89-104

5. Scheibye-Knudsen M, Fang EF, Croteau DL, Wilson DM, Bohr VA (2015) Protecting the mitochondrial powerhouse. Trends Cell Biol 25: $158-170$

6. Calvo SE, Klauser CR, Mootha VK (2015) MitoCarta2.0: an updated inventory of mammalian mitochondrial proteins. Nucleic Acids Res 44: D1251-1257

7. Craven L, Alston CL, Taylor RW, Turnbull DM (2017) Recent advances in mitochondrial disease. Annu Rev Genomics Hum Genet 18: 257-275

8. Nurminen A, Farnum GA, Kaguni LS (2017) Pathogenicity in POLG syndromes: DNA polymerase gamma pathogenicity prediction server and database. Biochim Biophys Acta 7: 147-156

9. Tzoulis C, Engelsen BA, Telstad W, Aasly J, Zeviani M, Winterthun S, Ferrari G, Aarseth JH, Bindoff LA (2006) The spectrum of clinical disease caused by the A467T and W748S POLG mutations: a study of 26 cases. Brain 129: 1685-1692

10. Blok MJ, Van den Bosch BJ, Jongen E, Hendrickx A, CDe Die-Smulders DE, Hoogendijk JE, Brusse E, de Visser M, Poll-The BT, Bierau J, de Coo IF, Smeets HJ (2009) The unfolding clinical spectrum of POLG mutations. J Med Genet 46: 776-785

11. Sacconi S, Salviati L, Nishigaki Y, Walker WF, Hernandez-Rosa E, Trevisson E, Delplace S, Desnuelle C, Shanske S, Hirano M, Schon EA, Bonilla E, De Vivo DC, DiMauro S, Davidson MM (2008) A functionally dominant mitochondrial DNA mutation. Hum Mol Genet 17: $1814-1820$

12. Gorman GS, Chinnery PF, DiMauro S, Hirano M, Koga Y, McFarland R, Suomalainen A, Thorburn DR, Zeviani M, Turnbull DM (2016) Mitochondrial diseases. Nat Rev Dis Primers 2: 16080

13. Gorman GS, Schaefer AM, Ng Y, Gomez N, Blakely EL, Alston CL, Feeney C, Horvath R, Yu-Wai-Man P, Chinnery PF, Taylor RW, Turnbull DM, McFarland R (2015) Prevalence of nuclear and mitochondrial DNA mutations related to adult mitochondrial disease. Ann Neurol 77: 753-759

14. Lightowlers R, Taylor R, Turnbull D (2015) Mutations causing mitochondrial disease: what is new and what challenges remain? Science 349: 1494-1499

15. Rusecka J, Kaliszewska M, Bartnik E, Tońska K (2018) Nuclear genes involved in mitochondrial diseases caused by instability of mitochondrial DNA. J Appl Genetics https://doi.org/10.1007/s13353-0170424-3

16. Baranowska E, Rytka J, Kucharczyk R (2018) Molekularne podłoże chorób spowodowanych mutacjami w genach kodujących podjednostki syntazy ATP. Postepy Biochem 64: 304-317

17. Vafai SB, Mootha VK (2012) Mitochondrial disorders as windows into an ancient organelle. Nature 49: 374-383
18. Chinnery PF (2015) Mitochondrial disease in adults: what's old and what's new? EMBO Mol Med 7: 1503-1512

19. Falk MJ, Shen L, Gonzalez M, Leipzig J, Lott MT, Stassen APM, Wong LJ (2015) Mitochondrial Disease Sequence Data Resource (MSeqDR): a global grass-roots consortium to facilitate deposition, curation, annotation, and integrated analysis of genomic data for the mitochondrial disease clinical and research communities. Mol Genet Metab 114: 388396

20. Mootha VK, Bunkenborg J, Olsen JV, Hjerrild M, Wisniewski JR, Stahl E, Bolouri MS, Ray HN, Sihag S, Kamal M, Patterson N, Lander ES, Mann M (2003) Integrated analysis of protein composition, tissue diversity, and gene regulation in mouse mitochondria. Cell 115: 629-640

21. Tońska K, Kodroń A, Bartnik E (2010) Genotype-phenotype correlations in Leber hereditary optic neuropathy. Biochim Biophys Acta 1797: 1119-1123

22. Hudson G, Carelli V, Spruijt L, Gerards M, Mowbray C, Achilli A, Pyle A, Elson J, Howell N, La Morgia C, Valentino ML, Huoponen K, Savontaus ML, Nikoskelainen E, Sadun AA, Salomao SR, Belfort R Jr, Griffiths P, Yu-Wai-Man P, de Coo RF, Horvath R, Zeviani M, Smeets HJ, Torroni A, Chinnery PF (2007) Clinical expression of Leber hereditary optic neuropathy is affected by the mitochondrial DNA-haplogroup background. Am J Hum Genet 81: 228-233

23. Wei W, Gomez-Duran A, Hudson G, Chinnery PF (2017) Background sequence characteristics influence the occurrence and severity of disease-causing mtDNA mutations. PLoS Genet 13: e1007126

24. Caporali L, Iommarini L, La Morgia C, Olivieri A, Achilli A, Maresca A, Valentino MI, Capristo M, Tagliavini F, Del Dotto V, Zanna C, Liguori R, Barboni P, Carbonelli M, Cocetta V, Montopoli M, Martinuzzi A, Cenacchi G, De Michele G, Testa F, Nesti A, Simonelli F, Porcelli AM, Torroni A, Carelli V (2018) Peculiar combinations of individually non-pathogenic missense mitochondrial DNA variants cause low penetrance Leber's hereditary optic neuropathy. PLoS Genet 14: e1007210

25. Gueven N, Faldu D (2013) Therapeutic strategies for Leber's hereditary optic neuropathy: A current update. Intractable Rare Dis Res 2: 130-135

26. Janssen MCH, Koene S, de Laat P, Hemelaar P, Pickkers P, Spaans E, Beukema R, Beyrath J, Groothuis J, Verhaak C, Smeitink J (2018) The KHENERGY Study: Safety and Efficacy of KH176 in Mitochondrial m.3243A>G Spectrum Disorders. Clin Pharmacol Ther doi: 10.1002/ cpt.1197

27. Zhang J, Liu H, Luo S, Lu Z, Chávez-Badiola A, Liu Z, Yang M, Merhi Z, Silber SJ, Munné S, Konstantinidis M, Wells D, Tang JJ, Huang T (2017) Live birth derived from oocyte spindle transfer to prevent mitochondrial disease. Reprod Biomed Online 34: 361-368

28. Watts G (2012) Novel techniques for the prevention of mitochondrial DNA disorders: an ethical review. Nuffield Council on Bioethics. Londyn nuffieldbioethics.org/project/mitochondrial-dna-disorders

\section{Mitochondrial diseases, progress in research and treatment}

\section{Katarzyna Tońska ${ }^{1}$, Joanna Rusecka ${ }^{1}$, Ewa Bartnik ${ }^{1,2, 凶}$}

${ }^{1}$ Institute of Genetics and Biotechnology Faculty of Biology, University of Warsaw, 5a Pawińskiego St., 02-106 Warsaw, Poland ${ }^{2}$ Institute of Biochemistry and Biophysics, Polish Academy of Sciences, 5a Pawińskiego St., 02-106 Warsaw, Poland

e-mail: ebartnik@igib.uw.edu.pl

Key words: mitochondrial DNA, mitochondrial diseases

\section{ABSTRACT}

Mitochondrial diseases are caused by dysfunction of the mitochondrial oxidative phosphorylation system and can be the result of mutations both in mitochondrial DNA and in nuclear DNA. Mitochondrial diseases collectively describe a diverse group of heritable disorders, which may present at any age and have a wide spectrum of clinical manifestations. This leads to highly variable presentations, making the diagnosis of mitochondrial diseases challenging. Recent advances in genetic testing and novel reproductive options hold great promise for improving the clinical identification and treatment of mitochondrial diseases. In this work we discuss what is new in understanding and diagnosis of mitochondrial diseases. 